\title{
The implementation of PSBB on the development of retail MSMEs with the COVID-19 pandemic as a moderating variable
}

\author{
M. Trihudiyatmanto
}

Faculty of Economics and Business, Al-Quran Science University (UNSIQ), Indonesia

\begin{abstract}
Purpose - This study aims to analyse the effect of the implementation of PSBB on the development of Retail MSMEs (micro, small, and medium enterprises).

Method - Respondents in the study were 100 respondents. The sampling technique used in this study was purposive sampling, with the criteria for Retail MSMEs actors in Garung District, Wonosobo Regency, and at least the business had been operating for one year. The data analysis technique used in this research was SEM Smart PLS.
\end{abstract}

Result - The development of Retail MSMEs was significantly influenced by the implementation of PSBB and was moderated by the Covid-19 pandemic.

Implication - This study can assist businesses and the government during a pandemic outbreak.

Originality - This is the first study examining the influence of a pandemic outbreak on the development of MSMEs in the retail industry.

Keywords: retail MSMEs, implementation of PSBB, covid-19, outbreak restriction, SEM, Indonesia 


\section{Introduction}

Micro, Small, and Medium Enterprises (MSMEs) activities are one of the business fields that can develop and be consistent in the national economy. MSMEs are an excellent forum for the creation of

JIEMB | 92 productive jobs. MSMEs are labour-intensive businesses, do not require specific requirements such as the level of education, expertise (skills) of workers, and business capital is relatively small, and the technology used tends to be simple.

Micro, Small, and medium enterprises (MSMEs) are an essential part of the economy of a country or region. Therefore, various efforts to develop MSMEs have been carried out. One of which is by raising and increasing new people or entrepreneurs in the field of MSMEs. The village community is given skills hoping that these skills will become a creative business that benefits the family economy and village communities. In addition, these creative endeavours can also open new opportunities and job opportunities for the community (Wahyudi, 2012).

The presence of modern retailers has given its colour to the development of the Indonesian retail industry. In a short period, several modern retail business actors with extraordinary capital capacity carried out their activities in Indonesia. Modern retailers are in the form of minimarkets, supermarkets, and even hypermarkets. These modern markets are scattered in every major city in Indonesia. The booming of modern retailers has made traditional markets even more challenged and most of the retail MSME actors in Indonesia.

The traditional market itself is one of the tools that can strengthen the economy. Small businesses in the traditional retail industry have proven not to be vulnerable to the effects of the multidimensional crisis that has hit Indonesia since 1997. Moreover, most Indonesian people continue to rely on traditional markets because of the number of middle-class workers. If the traditional market is abandoned to die because of modern markets and hypermarkets, the potential for unemployment will continue to increase (Jemabut, 2011).

Traditional markets and retail MSMEs also have several advantages. Some of the benefits are in naturally competitive services such as strategic location, wide sales area, complete diversity of goods, low prices, a bargaining system that shows 
familiarity between sellers and buyers. The dependence of retail MSMEs on strategic locations has an impact on the development of these MSMEs. Suppose regional or location restrictions are carried out. In that case, consumers become increasingly challenged to get access to fulfilment of daily needs. In the end, it will hinder the development of retail MSMEs themselves. Restrictions on location access or large-scale social restrictions (PSBB), must be carried out by the government if the Covid 19 pandemic continues to increase from day to day.

From the description above, the problem formulations and research questions are compiled as follows:

1. Does the implementation of PSBB affect the development of Retail MSMEs?

2. Has the Covid-19 pandemic affected the development of retail MSMEs?

3. Does the implementation of PSBB affect the development of Retail MSMEs with Covid 19 as a moderating variable?

\section{Literature review}

\section{Development of Retail MSMEs}

Competition between micro, small and medium enterprises (MSMEs) and traditional markets with modern market business actors are considered heavy. Therefore, it is necessary to have an umbrella for protection from the government for MSME players and traditional markets. The Chairman of the Regional Representative Council (DPD) of Indonesia, Oesman Sapta Odang, asked the government to impose restrictions on modern retail operations only to the provincial capital. He also hopes to limit the existence of modern retail. Furthermore, he considered that modern Retail should not touch rural areas.

The reason behind Odang's argument is based on similar complaints made by MSME actors from various regions. Therefore, Odang believes that regulations governing the existence of the modern retail market can be a solution. The regulation of the presence of modern retail in remote rural areas needs to be supported to provide leeway for traditional Retail MSME players to develop. Nevertheless, traditional Retail MSME actors also hope that the government and local governments will immediately reorganize 
the governance and licensing system of micro, small and medium enterprises.

The government asked the Indonesian Retail Entrepreneurs Association (Aprindo) to strengthen partnerships with Micro, Small, and Medium Enterprises (MSMEs). Minister of Trade Agus Suparmanto sees a decline in the share of traditional retailers that must be addressed immediately so as not to cause social upheaval. At the VII Aprindo National Conference in Jakarta (12/11), Agus said that modern retailers, who have access to goods procurement and distribution, must assist small shops in procuring merchandise.

Agus emphasized that the Ministry of Trade is encouraging modern retailers that are members of Aprindo to enter their goods into traditional Retail. With a stable supply, Agus hopes that this will provide sustainable benefits. Furthermore, he also mentioned Aprindo as a gathering place for retail entrepreneurs to have a strategic role in maintaining goods and price stability at the retail level, especially staple goods. With this collaboration, Agus predicts that the prospects for the retail business will be better in the future. Because, with the Indonesian economy growing by $5.02 \%$ in the third quarter of 2019 , the trade sector has contributed $13 \%$ of the total gross domestic product (GDP), and household consumption has contributed $56.62 \%$ of the real GDP.

In addition, another indicator that shows a positive trend comes from the growth in consumption of daily necessities or fast movers consumer goods (FMCG). Agus said FMCG consumption growth until September 2019 on an annual basis (year-on-year/YOY) grew positively by $2.5 \%$. The consumption of FMCG from modern retail grew $7.6 \%$. Minimarkets growing $12 \%$, while supermarkets and hypermarkets grew negatively by $5.8 \%$. This decline in consumption in the large retail format shows that there is currently a change in the consumption style of people who nowadays prefer daily shopping in a smaller form. Agus also advised retail businesses to be able to adapt and adapt business concepts to the market.

Most Indonesians continue to rely on traditional markets because many middle-lower classes workers are absorbed. Therefore, if the market can die because of modern markets and hypermarkets, the potential for unemployment will continue to increase (Jemabut, 2011). Nevertheless, traditional markets and retail MSMEs also have several advantages in naturally competitive 
services. These advantages include strategic location, wide sales area, complete diversity of goods, low prices, a bargaining system that shows familiarity between sellers and buyers, which is an advantage.

Previous research conducted by Indiarti and Langenberg (2004) regarding the development of MSME businesses states that the factors that influence traditional companies and retail MSMEs are the psychological capital of entrepreneurs, human resource management, innovation, characteristics of entrepreneurs, and characteristics of the business itself.

\section{Implementation of PSBB}

The National Disaster Management Agency (BNPB) recommended implementing large-scale social restrictions (PSBB) throughout Java. The implementation of the PSBB aims to reduce the curve of the Covid-19 surge. However not all regions have implemented the PSBB. Responding to this, the Governor of Central Java, Ganjar Pranowo, said that he fully supports the central government to implement the PSBB throughout Java Island. "We are ready with all scenarios. We will follow the command from the center. Anyway, what decisions from the centre will we support," Ganjar told reporters, Friday (15/5/2020).

He emphasized that he would begin to calculate the economic and logistical impact if the central government decided that the PSBB was implemented throughout Java. "The first preparation is to calculate the impact. Certainly, there will be a lot of people at home, and it will require logistics, certainly building a minimal transportation system," he said. In addition, continued Ganjar encouraged law enforcement to be carried out by cooperating with the TNI-Polri and all community forces. "Until now, don't forget the last front. In this case, the medical personnel and the hospital will complete it. But, anyway, all scenarios from our centre are ready," he said.

Deputy Governor of DKI Jakarta, Ahmad Riza Patria, said there are four indicators to end the implementation of large-scale social restrictions (PSBB). Currently, PSBB Jakarta has entered its third phase from May 22, 2020, to June 4, 2020.

"First, the RO (reproduction rate of the Covid-1 virus) is below the number 1," Deputy Governor of DKI Jakarta Ahmad Riza Patria told the Warta Kota Editor in a video conference via the Zoom 
application, Wednesday (27/5/2020) night. The second indicator is the readiness of facilities and infrastructure owned by DKI. Then, the third indicator, the number of residents who take the rapid test or swab test for coronavirus or Covid-19 in Jakarta, increases. "Furthermore, the fourth is a significant curve reduction (the Covid19 case). These are the four indicators of whether Jakarta after June 4 can enter the New Normal period or not" he said.

According to the Deputy Governor of DKI Jakarta, the success or failure of the PSBB in the third phase depends on the obedience of Jakarta residents. If the residents became more obedient, then the PSBB could be ended immediately. But, on the other hand, the more people ignore the PSBB, of course, the Covid-19 transmission will be even more massive, so the government tends to extend the PSBB.

\section{The Covid-19 pandemic}

Coronavirus or severe acute respiratory syndrome coronavirus 2 (SARS-CoV-2) is a virus that attacks the respiratory system. This disease due to viral infection is called COVID-19. The coronavirus can cause minor respiratory system disorders, severe lung infections (pneumonia), and death.

Severe acute respiratory syndrome coronavirus 2 (SARS-CoV2 ), better known as the coronavirus, is a new type of coronavirus that is transmitted to humans. Although it primarily affects the elderly, this virus can affect anyone, from babies to children to adults, including pregnant women and nursing mothers. Coronavirus infection is called COVID-19 (Corona Virus Disease 2019) and was first discovered in Wuhan, China, at the end of December 2019. This virus is spreading quickly and has spread to almost all countries, including Indonesia, in just a few months.

The virus has led several countries to implement policies to impose lockdowns to prevent the spread of the coronavirus. In Indonesia itself, a Large-Scale Social Restriction (PSBB) approach was implemented to reduce the spread of this virus. The West Java Provincial Government measures the effective reproductive rate (Rt) with SimcovID modelling (Simulation and Modelling of Indonesian Covid-19). SimcovID is a joint team consist of researchers from various universities, such as ITB, Padjadjaran University, YGM, UGM, ITS, UB, and Undana, and researchers from foreign universities, namely Essex \& Khalifa University, University of 
Southern Denmark, and Oxford University. Based on the Kalman Filter method, an extension of the Sequential Bayesian method, there are three indicators to measure the Covid-19 (Rt) reproductive index. Namely the number of active, positive cases, the number of cures, and the number of deaths based on daily time.

In connection with the Covid 19 pandemic, West Java divides zones/areas into several indicators according to colour. The division is as follows: Level 5 (black zone) critical (score 8-11) - economy $10 \%$, Level 4 (red zone) heavy (score 12-14) - economy 30\%, Level 3 (yellow zone) sufficient heavy (score 15-17) - economy 60\%, Level 2 (blue zone) moderate (score 21-24) - economy 90\%, Level 1 (green zone) low (score 21-24) - economy 100\%. Many other regions then followed this division to facilitate restrictions between regions in dealing with the Covid 19 pandemic. The colour becomes an indicator of how strong the Covid 19 pandemic is in an area, including Garung District, Wonosobo Regency, which is this research area.

\section{Micro, small, and medium enterprises (MSMEs)}

Several researchers have studied and attempted to provide input for the development of MSMEs in Indonesia. Among these researchers, Supriyanto (2006) concluded that in his research, it turned out that MSMEs could be a solution to poverty alleviation in Indonesia. Efforts to advance and develop the MSME sector will absorb more of the existing workforce and, of course, improve the welfare of the workers involved in it to reduce the unemployment rate.

Meanwhile, Handayani, Saputro, Hidayanto, and Budi (2010) see that Micro, Small and Medium Enterprises (MSMEs) in Indonesia have contributed a lot to the national GDP (Gross Domestic Product) of $55.56 \%$ based on data from the Planning Bureau of the State Ministry of Cooperatives and SMEs of the Republic of Indonesia, in the 2008 year. To expand market share and improve MSMEs competitiveness, MSMEs need an application to integrate and automate MSMEs' business processes.

Then researcher Darwanto (2013) made observations on the growth of MSMEs in the economy in Indonesia. MSMEs as part of the economy must also be more increase the competitiveness by making innovations. The competitive advantage based on innovation and creativity should be prioritized because it has long durability 
and long term. This study aims to formulate institutional strategies to encourage innovation and creativity of MSME actors and compare strategies to create strong institutions for the creation of creativity and art that can increase the competitiveness of MSMEs from several countries. MSME problems related to productivity include the lack of copyright protection for innovation and creativity.

\section{Marketing mix}

The scope of marketing is comprehensive. Goods and services must pass various stages of activities before reaching the hands of consumers. The broad range of activities is simplified into four marketing policies commonly referred to as marketing mix or 4Ps in marketing; the four components are product, price, promotion, and place. Place is divided into marketing channels, marketing coverage, location, supplies, and transportation will have a less beneficial impact if territorial restrictions are done during the Covid 19 pandemic. As a result, many retail MSMEs lack goods to be traded, thus hindering retail MSMEs' development.

Most of the studies have established a positive relationship between the implementation of PSBB. This study examines the positive effects of PSBB performance on the development of retail MSMEs in Garung District, Wonosobo Regency, and the Covid-19 pandemic support as moderation. In addition, this study aims to investigate the moderating role of the Covid-19 pandemic in the positive relationship between the implementation of PSBB and the development of retail MSMEs.

As shown in Figure 1, the research framework is well supported by the PSBB-Pandemic Covid 19-Development model for retail MSMEs. The development of retail MSMEs can be accelerated by limiting the operation of modern retail from remote areas. Some other ways to accelerate MSMEs is by making policy that regulate the existence of the modern retail market, strengthening the retail Entrepreneurs Association in partnership with Micro, Small and Medium Enterprises (MSMEs), encouraging modern retailers to include their goods to traditional Retail and the growing positive trend of consumption of daily necessities. 
The Covid-19

Pandemic
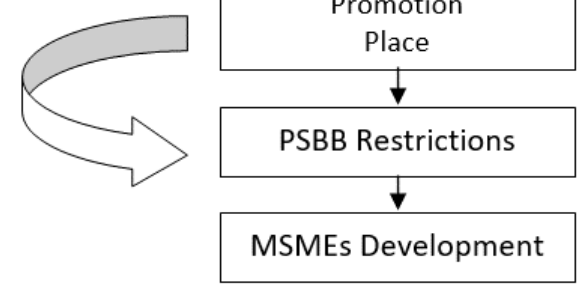

Figure 1. Modified marketing mix concept

The practice of implementing the PSBB easing is to give MSME entrepreneurs the freedom to work again, such as RO (the Covid-1 virus reproduction number) is below number 1 . Moreover, the local government's readiness of facilities and infrastructure, the number of residents who take the rapid test or swab test for the coronavirus or More and more Covid-19, significantly reduces the curve (Covid19 cases) (Reza Patria, 2020).

Furthermore, the context in which retail MSMEs operate and how the implementation of PSBB inhibits the broader spread of Covid-19 (Merry Dame Cristy Pane, 2020) so that the Covid-19 pandemic hampers creativity and development of retail MSMEs. The development of retail MSMEs during the implementation of PSBB is based on the theoretical framework and the relationship between the variables in this article.

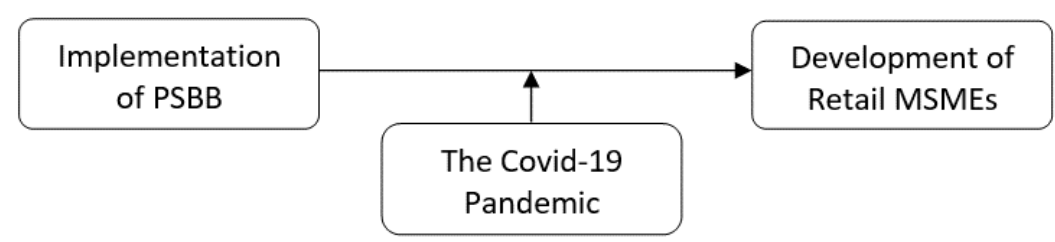

Figure 2. Research framework 


\section{Methodology}

In the current study, a cross-sectional survey approach was used in which data were collected from retail MSME actors in Garung District, Wonosobo Regency. There are 350 retailers. The

JIEMB | 100 sample size was previously determined using Krejcie and Morgan's (1970) benchmarks and Salkind's (1997) proposition, given the fact that levels of confidence and thoroughness are taken care of, and sampling error is minimized guaranteed by his approach. Therefore, out of a population of 350 , a sample size of 100 was chosen to stand for the entire study population.

In taking a sample of respondents from the entire population, this study used random sampling. During this pandemic, movement of researchers was limited so that only the sampling encountered was sampled (Sugiyono, 2015). Furthermore, the item for implementing the PSBB was adapted from Reza Patria (2020), while the MSME Retail development instrument was from Agus Suparmanto (2019). Items that support the Covid-19 pandemic adapted from Merry Dame Cristy Pane (2020). All items were scaled on a 5 -Likert scale. This study administered 125 questionnaires, but 100 questionnaires, representing 80 percent, were returned and further analyzed. SPSS 23 and Smart PLS 3.0 software packages were used for data analysis.

\section{Results and discussion}

The result involves demographic, descriptive, and inferential analysis. The demographic analysis presents demographic information on respondents, including gender, age, marital status, education level, experience, and position. The descriptive analysis describes the latent variables used in this study and concludes that the Initial step involves measuring models and evaluating structural models. Finally, an inferential analysis was performed using PLSSEM 3. PLS path modelling is comparable to conventional regression techniques. It can simultaneously examine the connection between the variable and the relationship between the indicator and the corresponding variable (e.g., measurement model) (Chin, Marcolin, \& Newsted, 2003; Duarte \& Raposo, 2010). In addition, PLS pathway modelling is considered suitable for exploratory studies, prediction-oriented, and theory-building 
extensions (Hair, Ringle, \& Sarstedt, 2011; Henseler, Ringle, \& Sinkovics, 2009).

Demographic and descriptive analysis

Most respondents in the sample (65 percent) were women, while the remaining 25 percent were men. Twenty-two percent of the respondents, indicating the majority, were in the age range of 25-30 years, with 36 percent representing the majority, having between 6 and 10 years of retail MSMEs entrepreneur experience. Sixty percent of respondents are married, while 35 percent and 5 percent are single and widowed. Furthermore, demographic analysis shows that a high proportion of respondents, representing 41 percent, are high school graduates, but first-rate holders constitute 25 percent. As many as 21 percent of the participants are holders of bachelor's and 13 junior high schools.

All the variables and their dimensions have a mean ranging from 4.12 to 4.13 . The standard deviation of all dimensions ranges from 0.6 to 0.61 . These values of overall means and standard deviations for all variables and their dimensions are acceptable. Therefore, it can be proved that the respondent's responses indicate acceptance and a satisfactory level of understanding concerning all research variables. The scale used in measuring the questionnaire items is a 1 to 5 Likert scale: strongly disagree, disagree, neutral, agree, and strongly agree.

Evaluation of the measurement model

Evaluation of measurement models involves indicator reliability, internal consistency reliability, convergent validity, and construct discriminant validity (Hair, Hult, Ringle, \& Sarstedt, 2014).

Table 1. Internal consistency and convergent validity

\begin{tabular}{lllll}
\hline Items & Items Loadings & AVE & Composite Reliability & Cronbach Alpha \\
\hline PSBB1 & 0,958 & 0,940 & 0,940 & 0,915 \\
PSBB2 & 0,898 & & & \\
PSBB3 & 0,878 & & & \\
PSBB4 & 0,835 & 0,948 & 0,948 & 0,926 \\
UMKM1 & 0,903 & & & \\
UMKM2 & 0,957 & & \\
UMKM3 & 0,929 & & 0,940 \\
UMKM4 & 0,829 & 0,807 & & \\
C1 & 0,899 & & & \\
C2 & 0,867 & & & \\
C3 & 0,850 & & & \\
C4 & 0,932 & & & \\
C5 & 0,940 & & & \\
\hline
\end{tabular}


Based on Hair et al. (2014), any item indicators with loading less than 0.4 should be removed. Thus this study filtered the model by removing all items that were below 0.4. As shown in Table 1 and Figure 3, one item was deleted, precisely from the item of MSMEs5. Thus, the load on hold items meets the 0.4 thresholds.

In addition, the reliability scores of the composite constructs ranged between 0.886, 0.940, and 1,000 (Hair, Black, Babin, \& Anderson, 2010), and the mean-variance extracted (AVE) of the constructs ranged between 0.813 and 1,000 , thereby exceeding the minimum requirements. 0.5 (Hair et al., 2011).

As depicted in Table 1, discriminant validity is considered satisfactory because each AVE latent construct appears more significant than the highest square correlation with the other latent constructs in the model. Figure 1, Table 1, and Table 2 show the evaluation results of the measurement model.

The estimation of the structural model is depicted in Figure 3 and Tables 3 and 4. The R-square value is 0.948 (see Figure 1), indicating that the implementation of PSBB explains 94.8 percent of the variance in the development of retail MSMEs. With beta values of $0.813,0.174$, and -0.002 at a significant level, namely less than $0.001 / 0.010$ for the direct effect of PSBB on MSME development of 0.000 . More than $0.001 / 0.010$ for the indirect effect through the Covid-19 pandemic of 0.088 and 0.905 , as shown in Table 3. From the result, it can be concluded that the findings of this study validate existing empirical findings and indicate that the implementation of

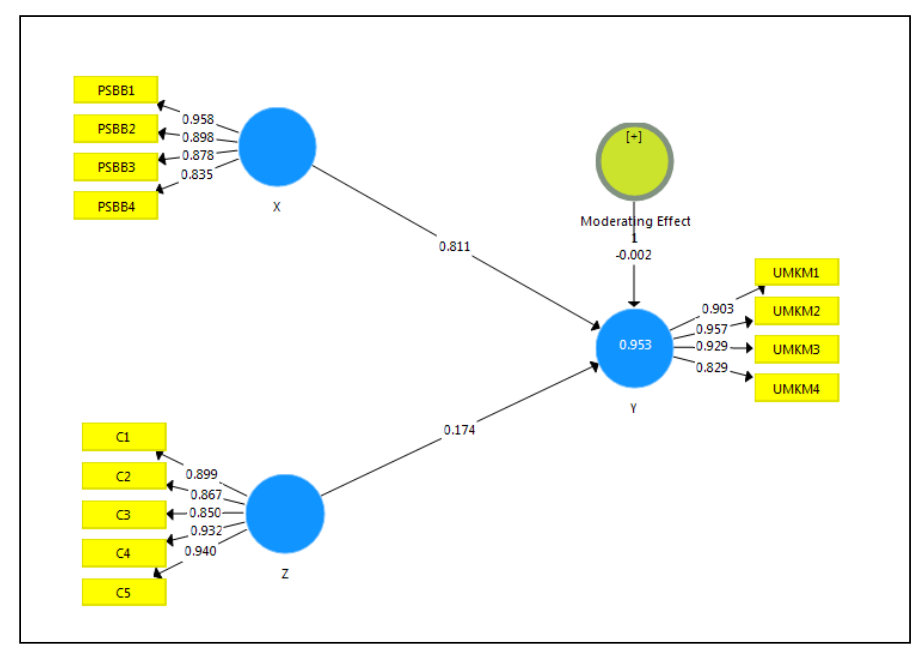

Figure 3. Measurement model 
Table 2. Discriminant validity

\begin{tabular}{lllll}
\hline & Moderating Effect & $\mathbf{X}$ & $\mathbf{Y}$ & $\mathbf{Z}$ \\
\hline Moderating Effect & & & & \\
$\mathbf{X}$ & 1.000 & & & \\
$\mathrm{Y}$ & -0.150 & 0.893 & & \\
$\mathrm{Z}$ & -0.157 & 0.974 & 0.906 & 0.898 \\
\hline
\end{tabular}

JIEMB | 103

PSBB has a positive effect on the development of retail MSMEs.

Meanwhile, the Covid-19 pandemic itself and as a moderating variable did not significantly affect the development of MSMEs. The result $(\beta=0.813, t=8,259, p<0.1)$ shows that the implementation of PSBB has a significant effect on the development of MSMEs. Thus, 1 hypothesis, out of 3 proposed hypotheses, is supported. Given the suggestions of Cohen (1988) and Hair, Hult, Ringle, \& Sarstedt (2013), the results in Table 4 indicate that the implementation of PSBB has a large measure of the development of MSMEs.

In addition, based on the Covid-19 pandemic approach, the results are described in Table $3(\beta=0.174, t=0.102, p>0.010 ; \beta=$ $-0.002, t=0.119, p>.010)$ indicating that the relationship between the implementation of PSBB and development Retail MSMEs do not depend on the support of the Covid-19 pandemic. In other words, support for the Covid-19 pandemic did not moderate the relationship

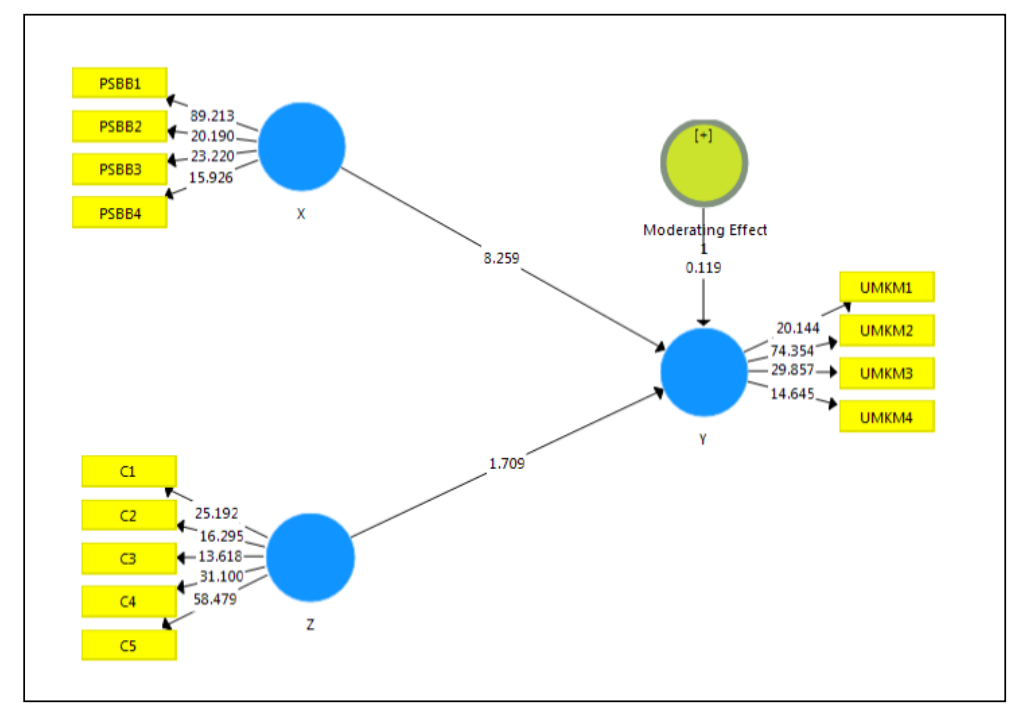

Figure 4. Model structural 
Table 3. Hypothesis testing

\begin{tabular}{lccccl}
\hline Constructs & Beta & Standar error & T-statistics & P-value & Decision \\
\hline $\mathrm{X}->\mathrm{Y}$ & 0,813 & 0,098 & 8,259 & 0,000 & Supported \\
$\mathrm{Z}->\mathrm{Y}$ & 0,174 & 0,102 & 1,709 & 0,088 & Not Supported \\
$\mathrm{X} * \mathrm{Z}-\mathrm{Y}$ & $-0,002$ & 0,017 & 0,119 & 0,905 & Not Supported \\
\hline
\end{tabular}

JIEMB | 104 relationship between the implementation of PSBB and the development of retail MSMEs.

The study's overall findings indicate that the implementation of PSBB is an effective driver for the decline in the development of Retail MSMEs. However, in some contexts, the development of MSMEs covers regional development, thus hampering the growth of MSMEs itself, but more importantly includes the absorption of labour. Research conducted by Supriyanto (2006) concluded in his study that MSMEs could be a solution to poverty alleviation in Indonesia. Efforts to advance and develop the MSME sector will be able to absorb more of the existing workforce and, of course, improve the welfare of the workers involved in it to reduce the unemployment rate.

Also, the results of this study indicate that the implementation of PSBB is a solid and positive predictor of the decline in the development of retail MSMEs. The implementation of PSBB hinders the development of market share, significantly increasing the competitiveness of MSMEs. Contrary to research from Handayani et al. (2010), they see that Small and Medium Enterprises (SMEs)

Table 4. Effect size on the endogeneous variable (PSBB)

\begin{tabular}{|l|c|c|c|c|}
\hline R-squared & Included & Excluded & f-squared & Effect Size \\
\hline $\mathrm{X} \rightarrow \mathrm{Y}$ & 0,953 & 0,951 & 1,726 & Big \\
\hline
\end{tabular}

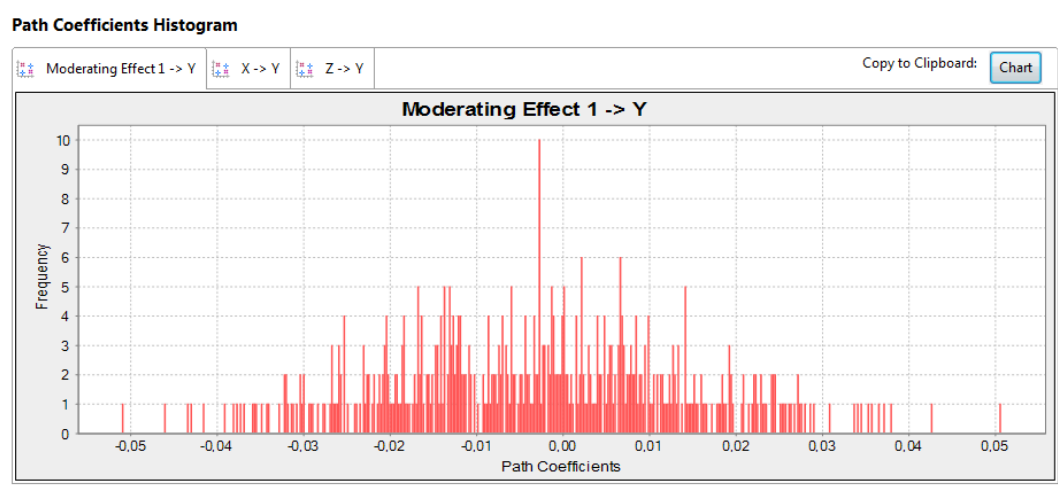

Figure 5. The Effect of Interaction on the Implementation of PSBB and Covid-19 Support and the Development of Retail MSMEs 
in Indonesia have contributed a lot to the national GDP (Gross Domestic Product) of $55.56 \%$ based on data from the Planning Bureau of the State Ministry of Cooperatives and the MSMEs Republic of Indonesia, in the 2008 year. To expand market share and increase MSMEs competitiveness, MSMEs need an application to integrate and automate MSMEs' business processes.

\section{Conclusion}

Overall, the findings of this study confirm that the positive effects of implementing PSBB can hinder the development of retail MSMEs. Also, current research findings have determined that the Covid-19 pandemic does not support strengthening the application of PSBB to the development of retail MSMEs. This means that the decline in the development of retail MSMEs itself is greatly influenced by the implementation of PSBB, which hinders the MSMEs players' activities. Not because of the covid-19 pandemic. The importance of the marketing area is that a large marketing area greatly influences the development of retail MSMEs. The findings of this study have offered more insight into the field of MSME research.

Although the results of this study promote the growth and development of knowledge in MSME research, they must be interpreted with caution, given the limitations associated with this study. The current study uses a cross-sectional research approach for data collection, but this approach does not guarantee that causal conclusions are made from the population (Sekaran \& Bougie, 2010). This is considered a limitation and thus affects the generalizability of the findings of this study. Therefore, the longitudinal research approach can be an alternative research approach for future research.

In addition, the relationship between the implementation of the PSBB did not depend on other factors on the decline in the development of MSMEs itself. However, it is necessary to study other factors that may positively moderate the relationship between the development of MSMEs in the Covid-19 pandemic era. Thus, future researchers can look for a moderator who can moderate the connection between the implementation of PSBB and the development of retail MSMEs. 


\section{References}

Chin, W. W., Marcolin, B. L., \& Newsted, P. R. (2003). A partial least squares latent variable modeling approach for measuring interaction effects: Results from a Monte Carlo simulation study and an electronic-mail emotion/adoption study. Information systems research, 14(2), 189-217.

Cohen, J. (1988). Statistical power analysis for the behavioral sciences (2nd ed.). Hillsdale, NJ: Lawrence Erlbaum.

Darwanto, D. (2013). Peningkatan Daya Saing Umkm Berbasis Inovasi dan Kreativitas (Strategi Penguatan Property Right terhadap Inovasi dan Kreativitas). Jurnal Bisnis dan Ekonomi, 20(2), 24200.

Duarte, P. A. O., \& Raposo, M. L. B. (2010). A PLS model to study brand preference: An application to the mobile phone market. In V. Esposito Vinzi, W.W. Chin, J. Henseler, \& H. Wang (Eds.), Handbook of partial least squares (pp. 449-485). Berlin/Heidelberg: Springer.

Hair, Joseph \& Black, William \& Babin, Barry \& Anderson, Rolph. (2010). Multivariate Data Analysis: A Global Perspective.

Handayani, P. W., Saputro, J. W., Hidayanto, A. N., \& Budi, I. (2010). Peta rencana (roadmap) riset Enterprise Resource Planning (ERP) dengan fokus riset pada Usaha Kecil dan Menengah (UKM) di Indonesia. Jurnal Sistem Informasi, 6(2), 140-145.

Jemabut, Inno. 2011. Berdayakan Pasar Tradisional. 8 Juli 2011. Downloaded on 7 April 2012. 15:45 from http://www.sinarharapan.co.id/content/read/

Kotler, Philip. (2009). Marketing Management (Edition 13). U.S.A: Pearson Prentice Hall.

Sarstedt, Marko \& Ringle, Christian \& Hair, Joe. (2017). Partial Least Squares Structural Equation Modeling. 10.1007/978-3-319-055428_15-1.

Sugiyono (2015). Metode Penelitian Kombinasi (Mix Methods). Bandung: Alfabeta.

Supriyanto, S. (2006). Pemberdayaan usaha mikro, kecil dan menengah (UMKM) sebagai salah satu upaya penanggulangan kemiskinan. Jurnal Ekonomi dan Pendidikan, 3(1), 17247.

Wahyudi, Bambang, 2012.Manajemen Sumber Daya Manusia. Sulita, Bandung.

https://economy.okezone.com/read/2017/08/16/320/1757044/hambatperkembangan-umkm-toko-retail-modern-di-daerah-harus-dibatasi 
https://health.grid.id/read/352164159/ridwan-kamil-tangani-

pandemi-covid-19-dengan-8-indikator-anies-baswedan-

dengan-satu-kesatuan-epicenter?page=all

https://wartakota.tribunnews.com/2020/05/27/ahmad-riza-patria-

beberkan-4-indikator-psbb-di-jakarta-dapat-diakhiri

https://www.alinea.id/bisnis/pemerintah-minta-pengusaha-retailgandeng-umkm-b1XpQ9oXl

https://www.alodokter.com/virus-corona

https://www.bbc.com/indonesia/indonesia-52520636 
M. Trihudiyatmanto

JIEMB | 108 